\title{
Asejire Dam and the host communities
}

\author{
T. D. T. Oyedotun \\ Department of Geography and Planning Sciences, \\ Adekunle Ajasin University, Akungba-Akoko, Nigeria
}

\begin{abstract}
The principal aim of the paper is to examine the nature of socio-economic impacts of the Asejire Dam (Ibadan, Nigeria) on the host communities. There are a range of difficulties experienced by the host, but principally rural communities of the dam area. Farming, which is the major economy of the study area suffered a great deal from the dam in terms of reduction in total land areas cultivated, farm sizes, types of crops grown and the distance of the farm to the settlement. Fishing at Olukeye-Asejire, which was previously the fishing centre, has been abandoned, thus the fishermen are forced to move upstream daily to fish, thereby losing some hours that could have been used for fishing in travelling upstream and back to their homes. The positive impacts of the dam on the communities, however, include increase in the volume of fish caught when compared with before the dam fishing outcome, and provision of employment at the dam site. The long-term social impacts of the dam emphasized by the study revealed the permanent relocation of three settlements: Papa, Asala and Onikeke. The paper concluded by recommending commercialisation of agriculture in the study area, construction of better roads to join the settlements which will aid easy and speedy evacuation of agricultural products, and the developments of Asejire dam as a tourist centre among other recommendations.
\end{abstract}

Keywords: Asejire Dam, River Osun, socio-economic impacts, host communities.

\section{Introduction}

The important role of water, as a basic necessity for humanity, cannot be overemphasized. It is the basis of life [1], therefore any developmental efforts of an area must include the development of water resources as one of its integral components. Chapter 18 of Agenda 21 [2, p. 275], adopted at the Earth Summit 
in Rio de Janeiro, summarised the overall goal of any water policy developments:
"water is needed in all aspects of life. The general objective is to make certain that adequate supplies of water of good quality are maintained for the entire population of this planet while preserving the hydrological, biological and chemical functions of ecosystems, adapting human activities within the capacity limits of nature and combating vectors of water-related diseases" ([2, p. 275]; [3, p. 5]).

Contemporary developmental efforts necessitate the development of water resources for various purposes to which they can be put to use. "However, water is a unique resource, having no substitute" [1, p. 189]. The provision of potable water contributes to the improvement in the personal hygiene and general sanitation of any community, hence, it is considered as a vital factor towards the attainment of a successful preventive health care programme [4].

Though water could be regarded as a common natural resource that could easily be found, not all water is safe for domestic use. Nace [5] in his paper on Are we running out of water, stated that out of the total earth surface covered by water, less than five percent $(5 \%)$ is fresh water and from the relatively small fraction, less than $0.5 \%$ is available for domestic and community use. This confirms the underlying principle that the water of good quality is scarce and only an economic management of it can optimize its benefit to man. Dams have been built for at least 5,000 years [6] and their functions have evolved with the developing needs of society. Most likely, the earliest dams were built to store water for domestic and agricultural water supply. With the outset of industrial era, hydropower became a major reason for building dams. As at present, dams are built to serve many other functions such as flood control, navigation and recreation. In Can the Dams? Fast, stated that "people construct dams for many reasons: to protect their homes and property, to generate power, for public water supply, irrigation, recreation, flood control, stock/ farm pond, to keep high water levels so boats don't bottom out, and even to create artificial lakes" [7, p. 44].

Dam projects on many occasions cause irreversible socio-economic and environmental changes over a wide geographic area and this have the significant impacts on the host areas [8]. Criticism of such projects has grown in the last decades. Several critics claim that because benefits from dams are outweighed by their social, economic and environmental costs, the construction of dams is unjustifiable (see [9-12]). Others contend that in some cases environmental and socio- economic costs can be avoided or reduced to an acceptable level, in case of future projects, by carefully assessing the problems and the numerous impacts of the existing dams on the neighbouring communities (e.g. [8, 13, 14]).

The area of influence of a dam extends from the upper limit of the catchments of the reservoir to as far downstream as the estuary, coast and off-shores zone. It includes the watershed and river valley below the dam [15]. While there are direct environmental impacts associated with the construction of the dam (e.g. dust, erosion, etc.), the greatest environmental impacts result from the impoundment of water, flooding of land to form the reservoir and alteration of water flow downstream. These effects have direct impacts on soils, vegetation, 
wildlife and human populations in the area $([16,17])$. Socio - economically, the benefits of dams often accrue to urban dwellers, agricultural interests and others living some distance away from the dam, but less so or not all to those who bear the heavy environmental and socio-economic costs of the dam constructionnamely the inhabitants of area inundated by the reservoir, and those living on the flood plain [8]. Floodplains of many tropical rivers of which River Osun is among has been an area of utmost importance to human and animal production, therefore when the floodplain is affected, the land-use will automatically change and the populations would be forced to move/relocate [11].

Almost everyone has some appreciation of how water projects have altered the course of civilization in ways we (perhaps foolishly) call benign. "Dams and reservoirs permit unimaginable numbers of people to inhabit forbiddingly arid region as well as flood plain where village would be washed away without upstream protection" [11, p. 68]. Historically, it can be demonstrated that those who reap the least benefits from dam building have been the nations/state majority population, while the greatest cost of building dams and reservoirs are being borne by the rural sectors who are traditionally excluded from the benefits of the dam construction.

This study is, therefore, intended to bring to the fore, the long- term socioeconomic impact of dam on the host/neighbouring communities at both upstream and downstream of the Asejire dam area.

\section{The study area}

The Asejire Reservoir is the current main source for Ibadan Water Supply Scheme. The dam was built in the late 1960s and was opened on 17 November, 1972 with a capacity of about 80 million litres of water per day, majority of which is consumed for domestic purposes [18]. The major purpose of the construction of the dam, otherwise known as Ibadan Water Supply Expansion Scheme was to supply the people of Ibadan with ample water supply for all their domestic and industrial activities [19].

The facility now completed under the scheme include a dam across the Osun River, with ancillary features, treatment plants, pumping stations, major pipelines, administrative buildings and staff houses. Bearing in mind the total area of land claimed for both the impoundment site and the dam site $(1,215.6$ lectures), one cannot but expect that the Asejire dam will definitely have some impacts on the people of this rural area of Egbeda Local Government of Oyo State (see fig. 1).

The study area is made up of five villages, which are: Olukeye-Asejire, Erinmi, Alabuke, Faleti, and Aba Alufa. These villages are within Egbeda Local Government area of Oyo state of Nigeria (see fig. 1). River Osun is the main river in the study area, and others like Omi, Idogun, and Okoseru are tributaries to it. These tributaries together with River Osun usually overflow their banks during the rainy season in May to October. But Osun is the only permanent river in the area, while some of the other that are tributaries to it are seasonal, some of them drying up completely during the dry season [20]. 
Table 1: $\quad$ General features of the Asejire Dam area.

\begin{tabular}{|l|l|}
\hline Parameter & Asejire Dam \\
\hline Location & $30 \mathrm{~km}$ East of Ibadan, Oyo State of Nigeria \\
\hline Latitude & $07^{\circ} 21^{\prime} \mathrm{N}$ \\
\hline Longitude & $04^{\circ} 07^{\prime} \mathrm{E}$ \\
\hline Elevation & $137 \mathrm{~m}$ above sea level \\
\hline Geology & Precambrian Metamorphic rocks \\
\hline Climate & Dry season: November to April \\
\hline & Rainy Season: May to October \\
\hline Annual Mean Temperature & $27.3^{\circ} \mathrm{C}$ \\
\hline Annual Mean rainfall & $14.7 \mathrm{~mm}$ \\
\hline Annual Mean humidity & $79 \%$ \\
\hline
\end{tabular}

Source: [21].

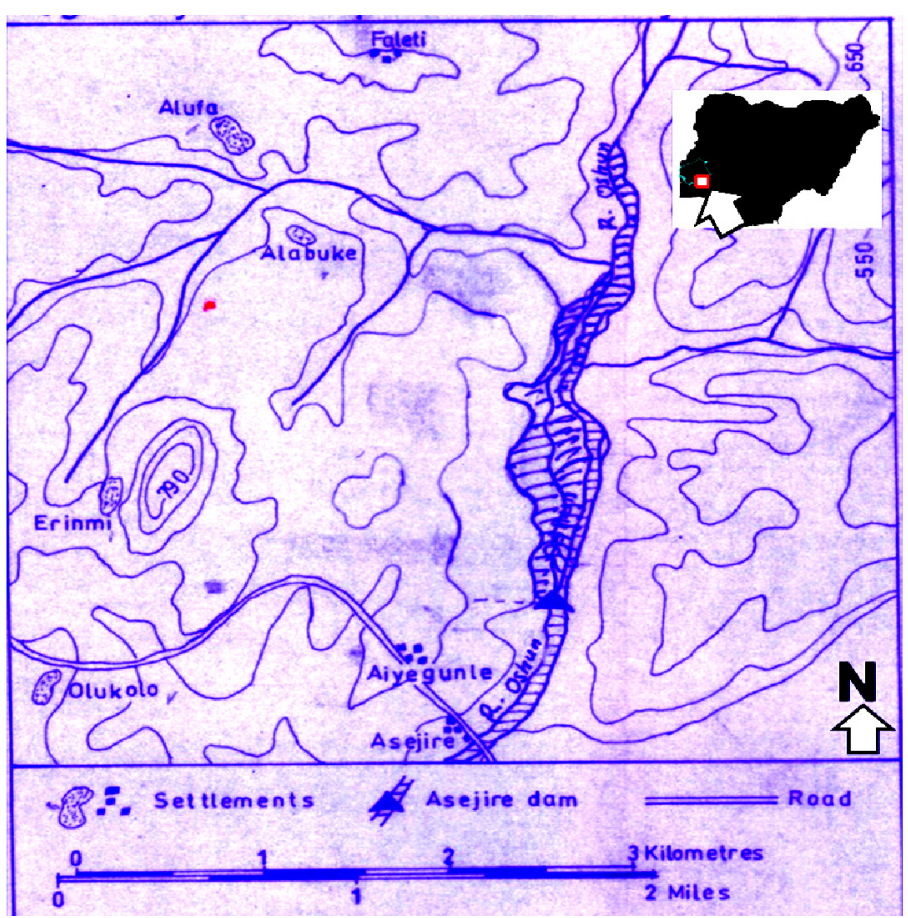

Figure 1: The study area showing Adejire Dam and the neighbouring/host communities. 


\section{Research methodology}

Complete interview of inhabitants in the neighbouring communities of Asejire Dam area is costly, time consuming and impracticable due to resource constraints. Consequently, a representative sample was chosen from each of the five villages under consideration. The settlements were chosen because of their closeness to the dam site. Also, the advice of the traditional rulers and dam officials who are very conversant with the communities, assisted in the choice of the settlements. The communities selected also have intimate knowledge of the dam.

The selection of five (5) settlements out of seven (7) was due to the willingness of the heads of those settlements to allow the researcher to carry out the survey questionnaire administration in their domains. The two traditional heads visited did not approve the administration of survey questionnaires. Having selected the five (5) settlements, households head in each settlement were systematically sampled taking every third household along each street. Where any particular household head refused to co-operate, he was omitted and another house was selected to replace it. Before interviews began, each prospective respondent was asked whether or not he was the head of the household and about the time of residency in the community, this was to ensure that the appropriate respondents were interviewed. The total number of questionnaire distributed in respect of each community and those retrieved are as shown in Table 2 below.

Table 2: Distribution of questionnaire in the neighbouring communities.

\begin{tabular}{|l|l|l|l|l|}
\hline $\begin{array}{l}\text { Name of } \\
\text { Community }\end{array}$ & $\begin{array}{l}\text { Total } \\
\text { Distribution }\end{array}$ & $\begin{array}{l}\text { Percentage } \\
\mathbf{\%}\end{array}$ & $\begin{array}{l}\text { Total } \\
\text { retrieved }\end{array}$ & $\begin{array}{l}\text { Percentage } \\
\mathbf{o}\end{array}$ \\
\hline Erinmi & 30 & 21 & 28 & 93.3 \\
\hline Olukeye & 60 & 41.9 & 60 & 100 \\
\hline Alabuke & 10 & 7 & 10 & 100 \\
\hline Faleti & 18 & 12.6 & 17 & 94.4 \\
\hline Aba Alufa & 25 & $17 ' 5$ & 24 & 96 \\
\hline Total & $\mathbf{1 4 3}$ & $\mathbf{1 0 0}$ & $\mathbf{1 3 9}$ & \\
\hline
\end{tabular}

Source: Author's Field Survey, April, 2008

Allocation of questionnaire to each settlement in the study area was based on two criteria. First is the population of each settlement. From the 2006 Census result, Olukeye-Asejire $(1,192)$ is the most densely populated, followed by Erinmi (566), Aba Alufa (324), Faleti (296) and Alabuke (201) [20] respectively.

The second factor that influenced the allocation was the extent to which the dam generated opposition particularly with respect to resettlement of the displaced settlements (Papa, Onikeke and Asala).

The view and opinion expressed by various classes of people and officials interview were organized and processed in logical sequence to unravel in a 
comprehensive manner the various issues raised in the study. The data collected by questionnaire survey have been processed and analysed using both descriptive and inferential statistics.

\section{Result and discussion}

\subsection{Economic impact of Asejire Dam on the host communities}

\subsubsection{Impact on farming}

This is the principal occupation of the people of the study area. From the fieldwork, it was discovered that 78.4 per cent of the sampled population were previously engaged in farming, although many of these people combine parttime activities such as tailoring, hunting, palm-wine tapping and produce buying.

Table 3: $\quad$ Previous occupations of respondents (before the dam).

\begin{tabular}{|l|l|l|l|l|l|l|l|}
\hline $\begin{array}{l}\text { Previous } \\
\text { Occupation }\end{array}$ & Erinmi & Olukeye & Alabuke & Faleti & $\begin{array}{l}\text { Aba } \\
\text { Alufa }\end{array}$ & Total & Percentage \\
\hline Farming & 25 & 46 & 07 & 10 & 21 & 109 & 78.4 \\
\hline Fishing & 02 & 12 & 01 & 04 & 03 & 22 & 15.8 \\
\hline Others & 01 & 02 & 02 & 03 & - & 08 & 5.8 \\
\hline Total & $\mathbf{2 8}$ & $\mathbf{6 0}$ & $\mathbf{1 0}$ & $\mathbf{1 7}$ & $\mathbf{2 4}$ & $\mathbf{1 3 9}$ & $\mathbf{1 0 0 . 0}$ \\
\hline
\end{tabular}

Source: Author's Field Survey, April, 2008

4.1.1.1 Sizes and location of farms. A dam project is expected to have a lot of effects on the farm size. Besides, the most important features of agriculture in Nigeria is its low technological level and the small scale of the majority of the holdings. Farm sizes in the study area are also very small as found in other parts of the country.

To test whether there is any significant difference between the previous and present farm sizes, forty (40) farmers were randomly selected from the list of one hundred and thirty nine (139) people interviewed and their previous and present farm sizes were subjected to statistical analysis. It was discovered that the mean of the previous farm size was 2.3975 (approximately 2.4) hectares, while at present the average farm size is 1.0475 (approximately 1.05) hectares.

With respect to distance of farmlands from home, a significant proportion (over 76 per cent) of the farms are located within 5 kilometres of the farmers' homes. However, some of the farms are located more than 5 kilometres from home; this is the case particularly with farmlands obtained outside the family land either by purchase or by pledge.

4.1.1.2 Types of crops. The agricultural pattern of this area falls into the production of cash crops and food crops. The major cash crops being produced in the study area include cocoa, kola nut, palm trees, oranges, coffee, and spices. 
The most important of these is cocoa. This crop was first introduced into the area around 1930. The cultivation of cocoa before the dam, from the information got during the interview, spread across almost all the villages.

There has been a marked reduction in the numbers of farmers that now grow cash crops. It should be noted that the percentage of farmers participating in food crops and mixture of food and cash crops farming increase with 27.3 and 12.0 per cent respectively; while the numbers of farmers growing cash crops decrease by 39.3 per cent. This reduction in the number of farmers growing each cash crop may be due to two main reasons. First and most important is that farmlands in the riverine area of the study area previously used for cultivation had been lost to the impoundment. Secondly, is that a great number of cocoa trees have and are still being attacked by the black pod disease of cocoa (Phytophoral palmivora).

Whatever might have been the cause of decrease in the number of farmers engaged in the cultivation of each cash crop, and hence a subsequent decrease in total hectares devoted to them, the resultant effect is that this has greatly affected the income of people since these are the income generating crops of these farmers.

As rightly stated, agriculture is the major occupation of the people of the study area. The long-term effects of the dam on farming are illustrated in terms of reduction in number of farmers, and reduction in total area of land cultivated. In terms of the location of farm relative to settlement, it is observed that the dam has greatly affected the pattern and number of farms located within each distance unit. It is clear that the construction of the dam has led to the loss of farms near the dam and along River Osun.

\subsection{Impact on fishing}

This is the second major occupation of the people in the study area before the dam. 15.8 per cent of the people were engaged in fishing before the dam which followed 78.4 per cent of people engaged in farming. But out of the 139 sampled, 25.9 per cent are practising fishing as at the time of the survey.

Out of the Thirty-six fishermen interviewed, twenty-two of them were around before the creation of the dam; hence the choice of the twenty-two fishermen. The analysis of the 2008 average income of the 22 fishermen interviewed showed that the \#7,190.90 (Naira) is higher than the previous average income of \#237.27 (Naira). The data were subjected to inferential statistics to see whether there is any significant difference between these two sets of income. The Analysis of Variance (ANOVA) test was carried out. From the table of "F" distribution, the tabulated " $F "$ value is 4.03 at 0.05 significant levels. It was therefore concluded that there is a significant difference between the income derived from the sales of fish by the fishermen before the opening of the dam and the present income derived from the sales of fish by fishermen.

Like farming, fishing is also affected to some degrees by the construction of the dam. The first obvious impact is that most of the fishermen have abandoned fishing at Olukeye-Asejire, which was previously the fishing centre. Consequently, the fishermen living at Olukeye-Asejire are forced to move upstream daily to fish thus losing some hours that could have been used for 
fishing in travelling upstream and back to their homes. Though it has been pointed out that there has an increase in the income of fishermen after the creation of the dam, the increase would have been more, if some valuable time are not wasted in moving to and from upstream to fish.

The creation of the dam and the hope that it is going to improve the volume of catch has led to the migration of some fishermen to the area. Majority of these migrants have come from the Eleiyele fishing centre in Ibadan.

Provision of Employment at the Dam Site: as it is usually expected of any dam, Asejire dam has been able to provide some people with employment. Because of the low literacy level, few of the natives who are employed in Asejire dam are employed as gatemen, labourers, cleaners and night guards.

\subsection{Social impact of Asejire Dam on the host communities}

Dams have a range of social impacts. Most importantly; dams have compelled the relocation of millions of people [8]. Considering our case study, three major settlements in the study area; Papa, Asala and Onikeke were asked to relocate without any provision for their relocations. The three rural settlements have given way for the impoundment of water in Asejire dam. The economic wellbeing and health of the settlements relocated were affected after the relocation. This was confirmed during the field interview. These communities were uprooted and dispersed causing the people to lose their social support network, as well as their livelihood and ways of life.

Another long-term social impacts of the dam is the loss of communities control over water. All the communities leaders interviewed said that they were/are not allowed to use the dam for any major thing; except for some few fishermen who have to pass through a lot of processes before being allowed to fish in the dam. When asked of whether the residents were allowed to use the dam for farming, fishing, or the nearby land for grazing, 98 per cent of the respondents attested "No" to the question; while only extremely few fishermen who were of about 2 per cent attested "Yes" to the question but they agreed that they had to obtain permission before the usage of the dam from Asejire Dam Authority.

The permanent impact of this is that the communities who had previously had unrestricted access to the use of River Osun have now lost the control to the State governments. Asejire Dam as a large scale, highly sophisticated technology, typically demanded much technical expert for various operations. This demand for expertise resulted in the management being taken over by Oyo and Osun State Governments. And as control over resources became more centralised, individuals and communities now lose the control that they once had over the resources they once depended on.

Other long-term human impact noticed and attested to by the communities in the study area is that various diseases have become more prevalent, as a direct consequence of Asejire dam. Malaria is a good example of diseases being experienced by over 93 per cent of the 139 interviewed. 30 per cent of this percentage noticed high intensity in the rate of malaria after the construction of the dam. Asejire dam also create excellent habitat for water borne disease 
parasites responsible for these diseases. For example, Asejire dam provides a good habitat for snails that spread schistosomiasis, and mosquitoes that spread malaria.

For a variety of reasons, the impacts of Asejire dam were felt disproportionately by women. Compensation to the displaced by the project were made to men; converting the collective assets of families into disposable cash held by the men. It was discovered that the compensation paid was cash as 100 per cent of the people interviewed during the field survey attested to being given the cash compensation; the actual amount had been forgotten by them. What is really certain is that men collected the compensation while the women, whose husband extravagantly spent the compensation, find themselves toiling and roaming in insufficiency and poverty till date.

\section{Recommendations and conclusion}

While the likely regime of the River Osun below the dam is yet to be established with certainty, the adverse effect the change in regime has had on the farming and fishing population below the dam emphasises the need for a comprehensive study of the problems and possible solution to them. A number of suggestion are now being be put forward:

- a comprehensive study to establish the new river regime, which will be of vital importance in planning for farming, fishing and navigation below the Dam;

- $\quad$ agriculture in the study area should be commercialised. To do this and for the economy of scale to be attained, farmers should be formed into co-operative unions and associations. New variety of high yield crops especially cocoa and other cash crops should be improved for farmers. Fertilizers should also be provided for the farmers in the study area at a highly subsidised rates;

- the settlements, apart from Olukeye-Asejire, which is on the main Ife Ibadan road, are connected to each other by foot paths, better roads should be constructed to join these hitherto poorly connected settlements;

- Also the fishing potentials of the area can only be fully tapped if fishermen are organised into co-operative fishing unions, and taught better methods of fishing and preservation. These fishermen should also be granted loans to purchase instruments such as canoes and nets, and;

- the transformation of the traditional economic activities will have to be undertaken in order to create the condition whereby these activities can significantly contribute to the economic growth of the country and provide the material basis necessary for the continue raising of the living standard of the people in the study area. For this, the researcher recommends that Asejire Dam should be developed as an organised tourist centre. This will provide more job /employment opportunities for the people in the rural area and will serve as a sort of income to Asejire Dam Authority; 
In conclusion, this study has shown clearly the extent to which Asejire Dam has affected the socio-economic activities of the neighbouring communities. If the above recommendations can be looked into, there will be a drastic reduction in the long -term negative impact of the dam on the host communities.

\section{References}

[1] Ayoade, J.O. (2006) Tropical Hydrology and Water Resources Management Agbo-Areo Publishers, Ibadan

[2] United Nations (UN) (1992) Agenda 21. Programme of Action for Sustainable Development. Official Outcome of the United Nations Conference on Environment and Development (UNCED), 3-14 June, 1992

[3] United Nations Educational, Scientific and Cultural Organisation (UNESCO) (2003) World Water Assessment Programme. Water for People, Water for Life. The UN World Water Report

[4] LSWC (1999) Annual Report of Lagos State Water Corporation. Lagos State Water Corporations (LSWC)

[5] Nace, R. L. (1967) Are we running out of water? U.S. Geologic Survey Circular 536

[6] Jansen, R.B. (1980) Dams and Public Safety. Water Resources Technical Publication. U.S Department of Interior, Water and Power Resources Services (USBR). Denver, Co.

[7] Fast, E. (2002) Can the Dams? Environmental. Oct.2002; pp 44-48

[8] Scudder, T (1997) Social Impact of Large Dams: Learning from the Past, Looking at the Future. World Conservation Union and World Bank Group Working Workshop Proceedings, Gland, Switzerland

[9] Williams, P.B. (1991) The Debate Over Large Dams. The Case Against Civil Engineer. August 1991

[10] Farradas, C. (1998) Report of Social Impacts of Dams: Distributional and Equity Issues - Latin American Region. Prepared for Thematic Review 1.1: Social Impacts of Large Dams Equity and Distributional Challenges

[11] Reisner, M. (2003) Unleash the Rivers Times, April/May 2000, 66-72

[12] Pearce, F. (2003) Feed the World. The Dammed. pp 182-194

[13] Barrow, C.J. (1981) Health and Resettlement Consequences and Opportunities Created as a Result of River Impoundment in Developing Countries. Water Supply and Management. Vol.5, 135-150

[14] De Villers, M. (2000) Water the Fate of Our Most Precious Resources. Houghton Mifflin, New York

[15] Baxter, R.M. (1977) Environmental Effects of Dams and Impoundment. Annual Review Ecological System. 8, 225-283

[16] Ludwig, H.F. (1982) Environmental Aspects of Multipurpose Reservoir Projects in Developing Countries. Water Science and Technology.14; 269-288

[17] Goodland R. (1986) Hydro and the Environment: Evaluating the Tradeoffs. Water Power and Dam Construction. Nov.1986, 25-33 
[18] Central Bank of Nigeria (1999) Urbanisation and related socio-economic problems of Ibadan Area. http://www.cenbank.org/out/ocasionalpp/ 2002/op-no25.pdf. Accessed on 05th May, 2010

[19] Oyedotun, T. D. T. (2011) Impacts of Asejire Dam on Discharge of River Osun, Oyo State of Nigeria. Proceedings of International Conference on Water Resources Engineering and Management, Lahore- Pakistan, 7.8 March, 2011, pp 115-121

[20] Anon, (1982) Ogun-Oshun River Basin Feasibility study. Vol. 4, OgunOshun River Basin Authority, Abeokuta.

[21] Ayoade, A. A., Fagade, S. O., and Adebisi, A. A. (2006) Dynamics of Limnological features of two man-made lakes in relation to fish production. African Journal of Biotechnology Vol 5(10), pp 1013-1021, 16 May, 2006

[22] National Population Commissions (2006) 2006 Population and Housing Census. National Population Commissions.

[23] Adeniyi, E.O. (1970) The Impact of the Change in River Regime on Economic Activities Below the Kainji Dam; NISER Reprint Series from The Journal of The Geographical Association of Nigeria. Vol. 13, No.2. 